\title{
Airline service quality evaluation: A review on concepts and models
}

\section{Navid Haghighat}

Shahed University,

Tehran Province, Tehran, Iran

MSc, Department of Industrial Management

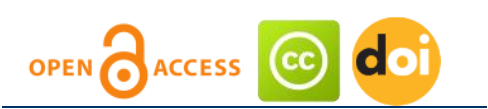

Article history:

Received: August 12, 2017

1st Revision: September

11,2017

Accepted: October 27, 2017

JEL classification:

C30

L84

021

DOI:

10.14254/jems.2017.2-2.4

\begin{abstract}
This paper reviews different major service quality concept and models which led to great developments in evaluating service quality with focusing on improvement process of the models through discussing criticisms of each model. Criticisms against these models are discussed to clarify development steps of newer models which led to the improvement of airline service quality models. The precise and accurate evaluation of service quality needs utilizing a reliable concept with comprehensive criteria and effective measurement techniques as the fundamentals of a valuable framework. In this paper, service quality models improvement is described based on three major service quality concepts, the disconfirmation, performance and hierarchical concepts which are developed subsequently. Reviewing various criteria and different measurement techniques such a statistical analysis and multicriteria decision making assist researchers to have a clear understanding of the development of the evaluation framework in the airline industry. This study aims at promoting reliable frameworks for evaluating airline service quality in different countries and societies due to economic, cultural and social aspects of each society.
\end{abstract}

Keywords: service quality models, service quality evaluation, airline industry, review of models and techniques.

\section{Introduction}

In today's competitive environment, delivering desirable service quality is vital for the airlines' survival, competitiveness, profitability and sustained growth. As a result of competitive pressure, delivering high-quality services to customers has become a marketing requirement for air carriers. Offering high-quality service leads to differentiating airline image from competitors and

Corresponding author: Navid Haghighat

E-mail: navid.haqiqat@gmail.com

This open access article is distributed under a Creative Commons Attribution (CC-BY) 4.0 license. 
assists in retaining existing passengers and enticing passengers from other airlines. In this rivalry, airlines need ways to keep essential service items and minimize efforts spent on less important service items while still maintaining passenger perceptions of airline service quality (Liou, Hsu, Yeh and Lin, 2011).

Since service quality is a multi-dimensional phenomenon and its determinants are situationdependent (Ghobadian, Speller, \& Jones, 1994), the need for a valuable framework to facilitate evaluating the quality of services that airlines offer to passengers is vital. Also, having an imagination of service quality development guideline in mind, aids airlines improve quality in required areas and update themselves rapidly with customer needs to have the chance of competition or even surviving in today's circumstances. Airline passengers have contacts with the employees of the company, physical and technical resources, such as in-checking desks, the plane itself, seats, meals and also have contacts with other passengers. Passengers' interactions with such human and non-human resources during the pre-flight, in-flight, and post-flight production processes effects on his evaluations of the service and on the service he perceives he has received (Swan and Combs, 1971).

Parasuraman, Zeithaml, and Berry (1985) declare because of service intangibility, a firm may find it more difficult to understand how consumers perceive services and service quality. Grönroos (1984) suggests that traditions and ideology (religion, political involvement, etc.) effects on customers' expectations and perceived performance of service quality. Chang and Yeh (2002) state that it is difficult to describe and measure airline service quality due to its heterogeneity, intangibility, and inseparability. They believe only customers can truly define service quality in the airline industry.

\section{Review of Service Quality Models}

After reviewing the literature three main parts are investigated: Concept, Technique, and Criteria (see Fig. 1) in the construction of the service quality evaluation frameworks. Since these parts are essential for the creation of an affordable service quality measurement instrument, studying development process of these principle parts is necessary.

In this paper service quality models with criticism of each model are described to demonstrate the roadmap of service quality improvement and make it more clear how service quality evaluation models are developed.

Figure 1: Main Parts of Service Quality Evaluation Frameworks

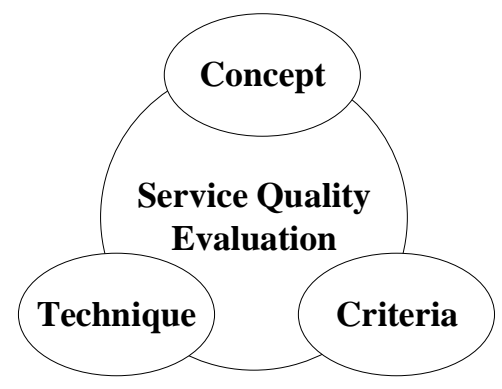

Although it is apparent that perceptions of service quality are based on multiple dimensions, there is no general agreement with the nature or content of these dimensions. In the following, major service quality concepts and models are described to help in demonstrating development process of service quality evaluation models.

\subsection{Measuring Service Quality or Satisfaction?}

In the literature, there is confusion in the relationship between consumer satisfaction and service quality. Parasuraman, Zeithaml, and Berry (1988) state that service quality is an antecedent of customer satisfaction but Bitner (1990); Bolton and Drew (1991) suggest that satisfaction is an antecedent of service quality.

Oliver (1980) believes that perceived service quality is a global judgment or attitude relating to the superiority of the service, whereas satisfaction is related to a specific transaction. Satisfaction soon decays into one's overall attitude toward purchasing products. He believes that satisfaction mediates the effect of service quality to cause a revised service quality perception to be formed and thus, Satisfaction rapidly becomes part of the revised perception of service quality. 
Cronin and Taylor (1992) state that practitioners always measure the determinants of overall satisfaction/ perceived service quality by having customers simply assess the performance of the company's business processes. They believe that judgments of service quality and satisfaction appear to follow the evaluation of a service providers' performance.it seems in many ways we can look at service quality and satisfaction as a compound unit.

\subsection{Disconfirmation Concept}

Disconfirmation concept states that after purchasing and using a product/service the consumer compares the quality of performance to his expectations. If the product/service performs as well as, or better than, expected he will be satisfied. If, however, performance is below expectations, dissatisfaction will result. The Disconfirmation conceptualizations in service quality mentioned by (e.g., Grönroos 1982, 1984; Parasuraman et al., 1985, 1988) are based on the researches studied disconfirmation paradigm to investigate consumer behavior and satisfaction with the products performance (Churchill \& Surprenant, 1982; Cardozo, 1965; Howard \& Sheth, 1969). This concept suggests quality results from a comparison of perceived with expected performance. There are two perspectives about disconfirmation concept that leads from the view of expectations toward attitude and behavior. The first perspective is mentioned by Parasuraman et al. (1988) that expectations are viewed as desires or wants of consumers, i.e., what they feel a service provider should offer rather than would offer, base on this view customers perceptions are compared to a maximum level of service quality which is always expected from the service provider.

In the second perspective, Oliver (1980) believes that expectations are consumer-defined probabilities of the occurrence of positive and negative events if the consumer engages in some behaviors. In this view, expectations are viewed as predictions made by consumers about what is likely to happen during an impending transaction or exchange and every time perceptions are compared to expectations. The level of perceived service quality is redefined which leads to further disconfirmation.

\subsection{Swan and Combs Model}

Swan and Combs (1976) examined the influence of physical and psychological dimensions of quality of product performance (Instrumental and expressive) with consumer satisfaction and post-purchase. In this model (see Fig. 2), The Instrumental performance would correspond to the performance of physical aspects of the product and the expressive performance would relate to the performance of nonmaterial and psychological aspects of the product. In clothing e.g., the durability of an item of clothing would be an instrumental performance dimension while styling would represent the expressive performance.

Swan and Combs declare if the performance of the physical product was below expectations, then the product is likely to be categorized as dissatisfactory. If the performance of both instrumental and expressive outcomes were equal to or exceeded expectations, then the consumers are satisfied with the product. They mentioned that satisfactory of instrumental performance is a prerequisite for consumer satisfaction, but it is not enough. Therefore, if the customer is not satisfied with the expressive performance of a product, the consumer will still feel unsatisfied, irrespective of the degree of satisfaction caused by the instrument performance. It clarifies the importance of expressive dimension in determining product /service performance.

In evaluating airline service quality, Swan and Combs state that passengers tend to rate the attributes related to instrumental performance like 'time saved' more than attributes related to expressive performance such as comfort, hostess, meals, and drinks. In ranking attributes, comfort was ranked after 'time saved' in the second place. They stated comfort seems to be related to instrumental dimension but the exploratory nature of the study suggests classifying this attribute in expressive dimension. 
Figure 2: Product performance Quality Dimensions

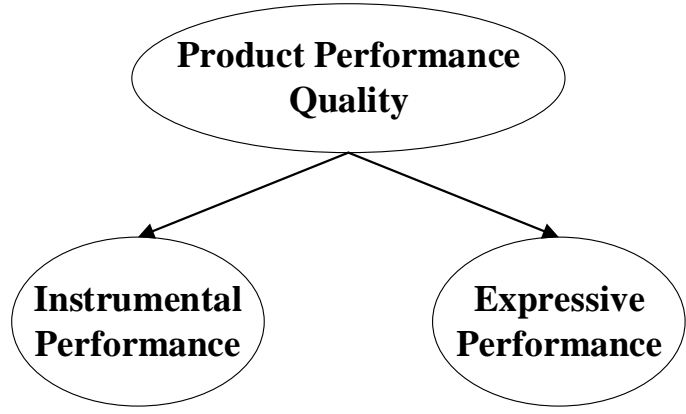

Source: Swan \& Combs, 1971

\subsection{Grönroos Model}

Grönroos (1982) identified three dimensions in service quality (see Fig. 3). Technical quality answers the question of what the customer gets, and functional quality answers the question of how he gets it. Actually Technical quality involves what the customer is actually receiving from the service, and functional quality involves the manner in which the service is delivered. The corporate image is the result of how the consumers perceive the firm.

Figure 3: Service quality dimensions

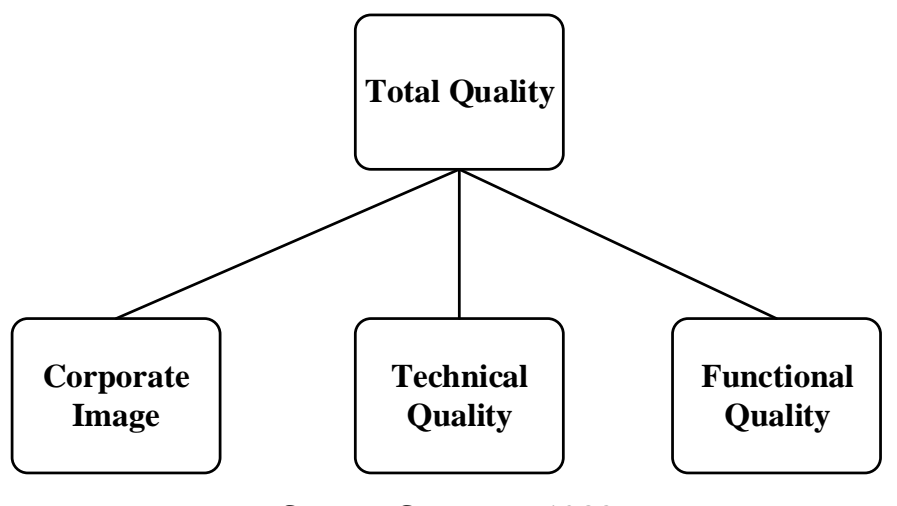

Source: Grönroos, 1982

Grönroos (1984) developed this model and suggested that the quality of the service is dependent on expected service and perceived service variables (see Fig. 4). He stated that the perceived quality of a given service will be the outcome of an evaluation process, where the consumer compares his expectations with the service he perceives he has received. The corporate image can be expected to be built up mainly by the technical and functional quality of its services. Grönroos believes that the expectation of the service comes from traditional marketing activities and external influences like ideology and word of mouth.

Figure 4: Service quality dimensions

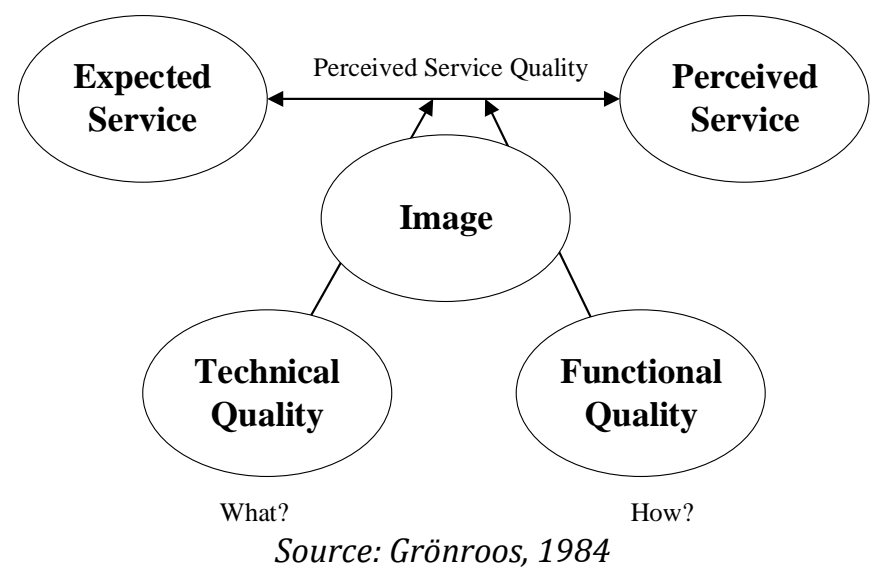




\subsection{SERVQUAL Model}

In SERVQUAL model, quality is defined as the gap between customers' expectations and perceptions $\mathrm{Q}=\sum(P-E)$, in which a customer will perceive quality positively only when the service provider meets or exceeds his expectations. Base on disconfirmation concept, Parasuraman et al. (1988) designed two questionnaires one for scoring items base on expectation and one for scoring items base on perception. Then they compared customers' expectations to actual service performance with the scores extracted from the two questionnaires. They suggested expected service is shaped by word-of-mouth communications, personal needs, and past experience.

Parasuraman et al. (1988) argued regardless of the type of service, consumers evaluate service quality using similar criteria which are grouped into five dimensions. These dimensions are described as: (1) Tangibles. Physical facilities, equipment, the appearance of personnel, and communications materials. (2) Reliability. Ability to perform the promised service dependably and accurately. (3) Responsiveness. Willingness to help customers and provide prompt service. (4) Assurance. Knowledge and courtesy of employees and their ability to inspire trust and confidence. (5) Empathy. Caring, individualized attention the firm provides its customers. These five dimensions were derived from 10 overlapping dimensions (reliability, responsiveness, customization, credibility, competence, access, courtesy, security, communication, tangibles, and understanding) which were regarded as service quality essentials proposed by Parasuraman et al. (1985) exploratory research. The five dimensions of SERVQUAL model with 22 items measurement scale (see Fig. 5) has been widely applied to various industries, including airline industry (Park, Robertson, and Wu, 2006; Gilbert and Wong, 2003).

Figure 5: Service quality dimensions in SERVQUAL model

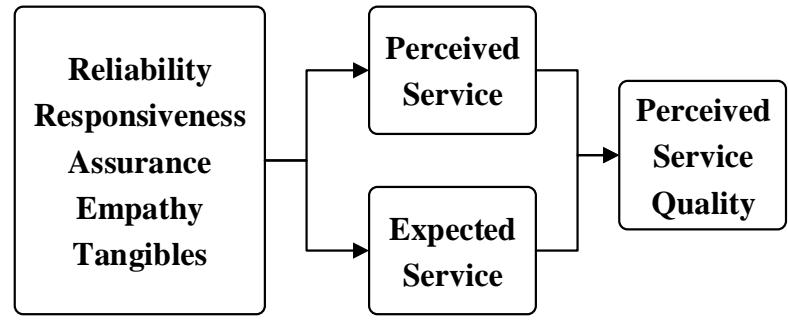

Source: Parasuraman et al., 1988

\subsection{The criticisms of SERVQUAL Model}

SERVQUAL is the most widely known and discussed scale for measuring service quality. However, it has been highly criticized in the literature. Major criticisms with SERVQUAL are discussed below:

\subsubsection{Criticisms of generality of dimensions}

Although Parasuraman et al. (1988) argued that regardless of the type of service, consumers evaluate service quality using similar criteria, which can be grouped into five dimensions, Rao and Kelkar (1997) mentioned that the generality of SERVQUAL dimensions across different service industries is questioned. Gilbert and Wong (2003) and Liou et al. (2011) declared although SERVQUAL has been widely used to measure service quality in a variety of industries, no two providers of a service are exactly alike. Chang and Yeh (2002) claim that service quality attributes are context dependent and should be selected to reflect the service environment investigated. Carman (1990) note that five dimensions of SERVQUAL are not generic and suggested that the instrument should be adopted by adding items or factors as pertinent to different situations. Park et al. (2006) state that five dimensions and 22 items of SERVQUAL scale are difficult to apply in the airline industry because this scale has not addressed some important criteria in airline service quality, such as in-flight meals, seating, comfort, seat space and leg room. 


\subsubsection{Criticisms of measuring expectation}

McDougall and Levesque (1994) suggest that including expectation scores on a service quality instrument may be inefficient and unnecessary. Babakus and Boller (1992) state that people tend to indicate consistently high expectation ratings and their perception scores rarely exceed their expectations. Wall and Payne (1973) believe that when people are asked to indicate the "desired level"(expectations) and the "existing level"(perceptions) of the service, there is a psychological constraint that people always tend to rate expectations higher than perceptions $(E>P)$.

\subsubsection{Criticisms of disconfirmation measurement (perception minus expectations)}

Cronin and Taylor (1992) believed that SERVQUAL has a naturally flawed concept because of its ill-judged adoption of perception minus expectation measurement scale. They indicated that a psychometrically superior assessment of service quality (in terms of construct validity and operational efficacy) can be obtained through the SERVQUAL performance items alone. Babakus and Boller (1992) stated that respondents appear to be bored and sometimes confused by the administration of E and P version of SERVQUAL. Study of Bolton and Drew (1991) demonstrated that that perceive service quality is strongly affected by current performance and the impact of disconfirmation is relatively weak and transitory.

\subsubsection{Criticisms of the questionnaire}

Dabholkar, Thorpe, and Rentz (1996) mentioned that some of the questionnaire items are inappropriate in terms of wording and meaning. Carmen (1990) expressed that using two questionnaires individually to measure expectations and perceptions as different scores, is inappropriate in terms of scale reliability and questionnaire length.

\subsubsection{Criticisms of overlapping dimensions}

Researchers had found structural problems with the inconsistent perceptions of some of SERVQUAL dimensions which makes it difficult to classify some attributes in a specific dimension. Robledo (2001) stated that the responsiveness, empathy and assurance dimensions show considerable overlap and load on the same factor. Fick and Ritchie (1991) failed to determine the relative impact of various SERVQUAL items on overall service quality and satisfaction. Spreng and Singh (1993) performed a confirmatory factor analysis on SERVQUAL and found a poor fit of the five dimensions model. They found a lack of discriminate validity between responsiveness and assurance and noted that although modification indices were high, there was no clear indication for ways to improve the model fit.

\subsection{Performance-based Concept}

Cronin and Taylor (1992) suggest that performance alone (current perception) better determines satisfaction than expectations and disconfirmation paradigm and the marketing literature appears to offer considerable support for the superiority of simple performance-based measures of service quality ( Bolton \& Drew, 1991; Churchill \& Surprenant, 1982; Mazis, Ahtola, \& Klippel, 1975). Bolton and Drew (1991) found that disconfirmation appears only to mediate, not define consumers' perceptions of service quality. Mazis et al. (1975) stated that Performance dimension alone is able to predict behavioral intentions. They suggested using only performance perceptions to measure service quality. Babakus and Boller (1992) found that service quality as measured in the SERVQUAL scale relies more significantly on the perception score than on the expectation score. Cronin and Taylor (1992) believe that current performance adequately captures consumers' perceptions of the service quality.

\subsection{SERVPERF Model}

Cronin and Taylor (1992) suggested that service quality evaluation should be performancebased. They called their model SERVPERF which measures service quality based on customers' perceptions of performance only $\left(\mathrm{Q}=\sum P\right)$. SERVPERF measurement explains more of the variance 
in an overall measure of service quality than SERVQUAL. They believe that undoubtedly, boredom and confusion of disconfirmation measurement of SERVQUAL model adversely affect data quality. This scale provides more construct-valid explication to service quality due to the content validity. Therefore, perception-only-measure seems to be more realistic and applicable in service quality evaluation. Cronin and Taylor also found that Importance-weighted evaluation of performance can be used instead of expectations since it is able to demonstrate perceived performance approximately to expected performance.

\subsection{The criticisms of SERVPERF}

This model is a variation of SERVQUAL that uses the same criteria of SERVQUAL model. Thus, the criticisms with SERVQUAL dimensions construct will remain with SERVPERF, yet. For example, Cunningham, Young and Lee (2004) state that SERVPERF has failed to measure airline industryspecific dimensions of service quality because of using the same SERVQUAL dimensions and items.

\subsection{Hierarchical Concept}

It is apparent that service quality evaluations are highly complex processes that may operate at several levels of abstraction (Carman, 1990). Therefore, it raises the importance of appearing a unifying theory or conceptualization that reflects this complexity and the hierarchical nature of the service quality model constructs. Customers form their service quality perceptions based on an evaluation of performance at multiple levels and ultimately combine these evaluations to arrive at an overall service quality perception. The combination of all subdimensions constitutes a customer's overall perception of service quality (Brady \& Cronin, 2001).

Many researchers suggest that service quality models should be based on a hierarchical concept (Dabholkar et al., 1996; Brady \& Cronin, 2001; Wu \& Hsu, 2012). Hierarchical structure models are believed to better explain the complexity of human perceptions than former conceptualizations. The hierarchical conceptualization aids service provides to understand how customers assess service encounters and assist them to obtain the judgments of customers about each of the key aspects of the service from the most disaggregated level (subdimensions) to the unique value of global service quality. Thus, designing service quality evaluation models based on hierarchical concept assist managers in proposing a valuable strategic tool to know about the weakness and strength of their company performance (Caro \& Garcia, 2007).

\subsection{RSQS Model}

Dabholkar et al. (1996) proposed a hierarchical model of service quality, called Retail Service Quality Scale (RSQS) in which retail service quality is viewed as a higher-order factor with performance-based measurement. They believe this scale is regarded suitable for use in retail businesses which offers a mixture of services and goods, such as department or specialty stores.

In defining the hierarchical structure of the model, Dabholkar et al. (1996) stated that some dimensions are complex and have more than one component related to them. To combine related attributes into subgroups, each of these dimensions should involve some subdimensions. So, this multilevel model is defined by two additional levels of attributes: dimensions level and subdimension level.

RSOS model as shown in Fig. 6 includes five primary dimensions: physical aspects, reliability, personal interaction, problem solving and policy; and six subdimensions: appearance, convenience, promises, doing it right, inspiring confidence and courteous. This model has 28 items, consisting of 17 items from SERVQUAL and 11 items developed from the literature review. 
Figure 6: Dimensions of Retail Service Quality Scale

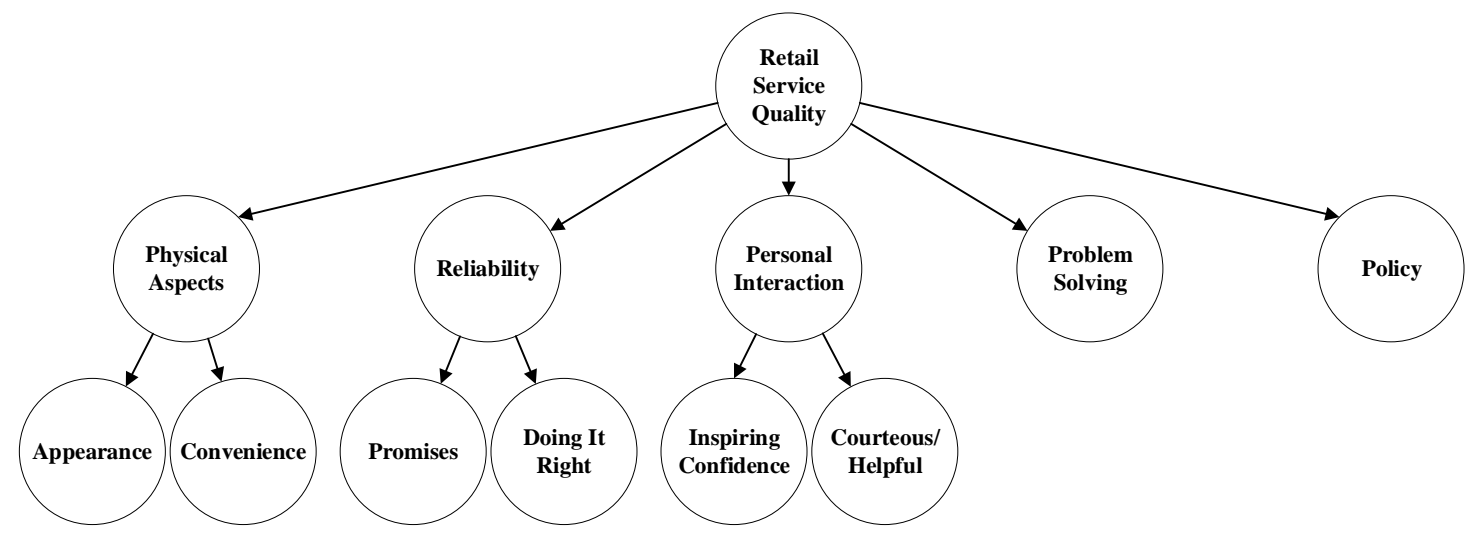

Source: Dabholkar et al., 1996

\subsection{The criticisms of RSQS Model}

Although Dabholkar et al.'s (1996) research contributed to a greater understanding of service quality in certain retail stores, it was criticized, because it failed to investigate the relationship between customer perceptions of the quality of the products a retailer carries and customer perceptions of service quality provided by the retailer (Finn \& Kayande', 1997).

Siu and Cheung (2001) believed that RSQS has not been tested in different cultures and has not the generalizability to investigate the important elements in delivering services in the context of department stores. Not all of RSQS main dimensions include subdimensions, which is inappropriate with the hierarchical concept. The main dimensions of Problem solving and Policy are not measured through subdimensions and directly through measurement items. Marks and Garcia (2007) state that Dabholkar et al. (1996) did not test RSQS as a global third-order model base on the hierarchical concept so this model lacks consistency and validity.

Moreover, they mentioned that Dabholkar et al. (1996) tested the primary dimensions considering the global service quality as a higher-order factor, with the assumption that those dimensions don't contain subdimensions.

\subsection{Brady and Cronin Model}

Brady and Cronin (2001) developed a hierarchical and multidimensional model of perceived service quality base on Dabholkar et al. (1996) hierarchical approach with a new look to SERVQUAL model. This model is described as a third-order factor model in which service quality is explained in terms of three primary dimensions: interaction quality, physical environment quality, and outcome quality. Each of these dimensions consists of three corresponding subdimensions: attitude, behavior, and experience (interaction quality); ambient conditions, design, and social factors (physical environment quality); waiting time, tangibles and valence (outcome quality).

The idea behind developing this model is that the five dimensions of SERVQUAL are terms which might be used to determine some aspect of service quality. Brady and Cronin (2001) state that SERVQUAL dimensions capture how consumers differentiate performance on these subdimensions. They believe this approach may account for the problematic factor structure of the SERVQUAL scale mentioned by (Carmen, 1990; Cronin \& Taylor, 1992). So they repositioned SERVQUAL factors as modifiers of the nine subdimensions of the model.

In the construction of this model, the reliability[R], responsiveness[SP], and empathy[E] variables are retained but they are not identified as direct determinants of service quality. Rather, they serve as descriptors of the nine subdimensions identified in the qualitative study. Brady and Cronin's model (see Fig. 7) consists of 35 items to measure these nine subdimensions. The 'social factors' subdimension is classified in two categories since they believe that the appearance and behavior of customers not only influence perceptions of the physical environment but also can enhance or detract from the service outcome. 
Figure 7: Dimensions of service quality

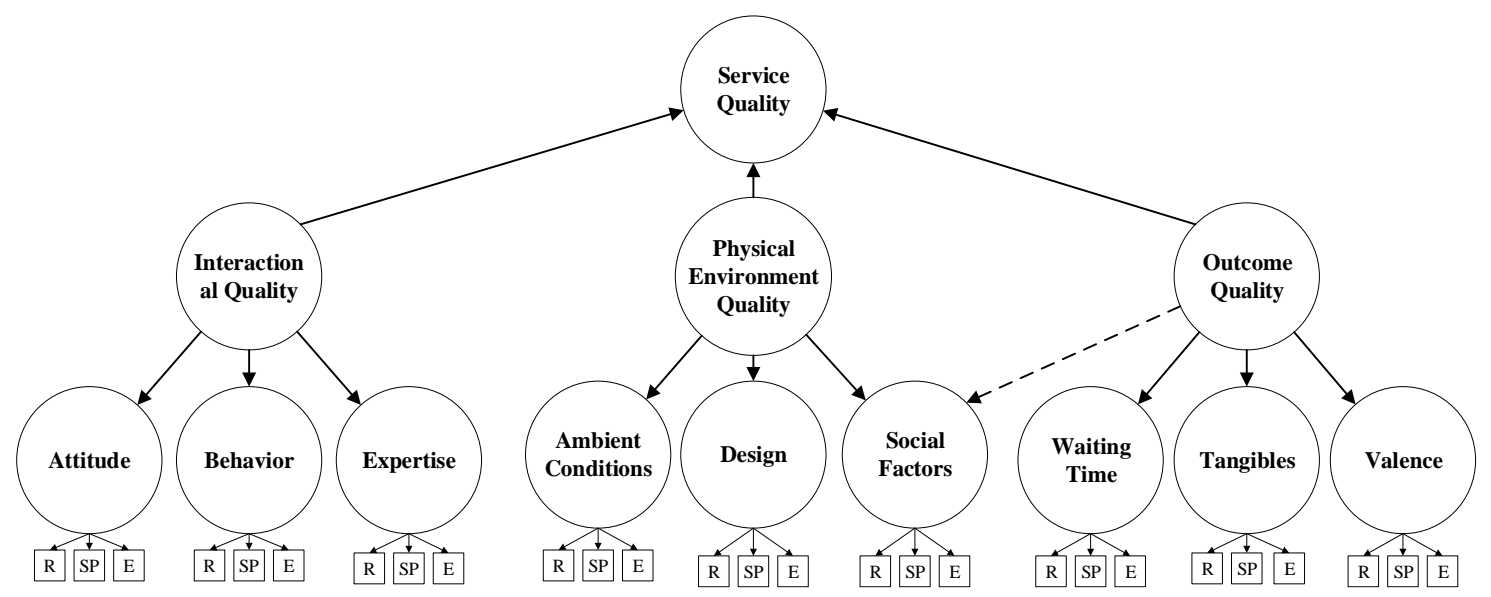

Source: Brady and Cronin, 2001

\subsection{The criticisms of Brady and Cronin Model}

Inconsistent with definition of hierarchical concept, Brady and Cronin (2001) added some items without intermediaries to evaluate the primary dimensions and the overall service quality but the implicit assumption of dimensions as antecedents of service quality and evaluation of main dimensions is only done thorough subdimensions measurement in the hierarchical concept.

Caro and Garcia (2007) states that if customers form their perceptions of service quality on the basis of the low level of abstraction (subdimensions), the sequence of analysis must be accomplished from the low to the high level of abstraction, using the nested sequence to compare multi-levels alternatives (e.g. Marsh \& Hocevar, 1985) but same as Dabholkar et al. (1996), Brady and Cronin (2001) tested the primary dimensions considering the global service quality as a higher-order factor, with assumption of unidimensionality of main dimensions.

\subsection{Caro and Garcia Model}

Caro and Garcia (2007) proposed a service quality evaluation model in urgent transport service in a multi-level hierarchical structure with four specific dimensions and nine subdimensions. They state the dimensions are not antecedents of service quality but rather expressions of the complexity of the construct. Service quality is a higher-order factor underlying the dimensions and changes in the perceived service quality produced by the variation in the perception of one dimension will affect the perception of the rest of dimensions due to the correlation among them. In this model four dimensions as shown in Fig. 8 are explained by their respective subdimensions and finally, the questionnaire items are indicators representing of each subdimension.

Figure 8. Dimensions of service quality in urgent transport service

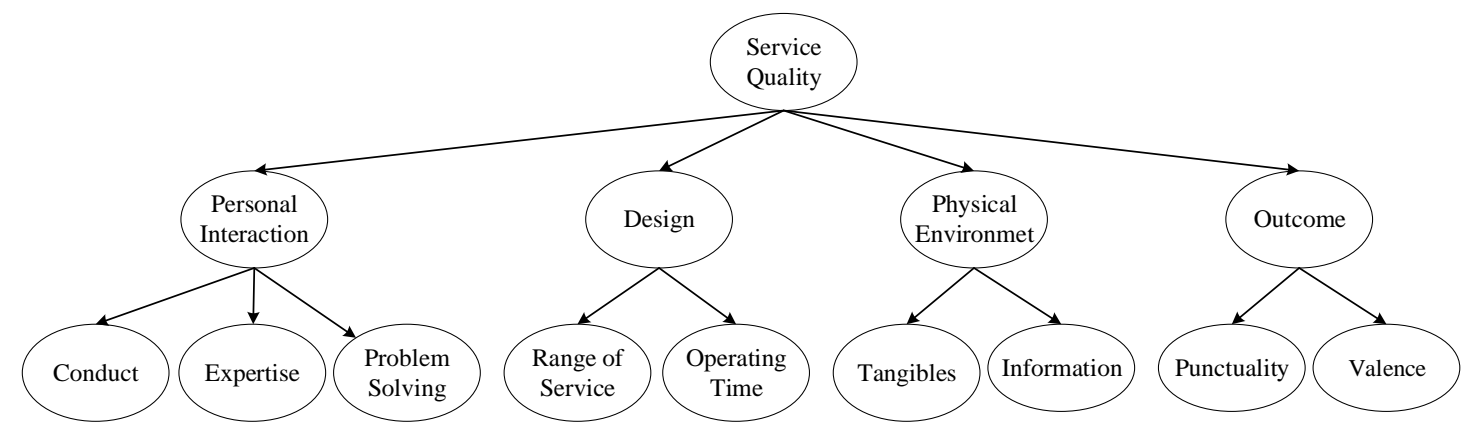

Source: Caro and Garcia, 2007 


\subsection{The criticisms of Caro and Garcia Model}

Caro and Garcia (2007) did not test structural equation modeling to obtain the paths and relationships of constructs of the model had not analyzed to strengthen validity of the model. Moreover, this model needs justifying for use in different transport systems and industries.

\section{Development of airline industry-specific service quality models}

Two important airline service quality models developed based on the evolution of important service quality models are discussed to demonstrate how airline service quality evaluation models are developed and improved.

\subsection{SERVPEX Model}

Robledo (2001) introduced SERVPEX model in evaluating airline service quality. This model with three dimensions and 26 items focused on improving SERVQUAL and SERVPERF models. SERVPEX dimensions (shown in Fig. 9) are described as: Tangibles; The appearance of airplanes, physical facilities, equipment, personnel, and communications materials, and the appearance and taste of food and beverages served on board. Reliability; The ability to perform the promised service dependably and accurately. Customer care (a dimension consisting basically of responsiveness, empathy, and assurance); Attitude and ability of employees to provide personalized service in a courteous, efficient and secure manner.

\section{Figure 9: Dimensions of airline service quality in SERVPEX}

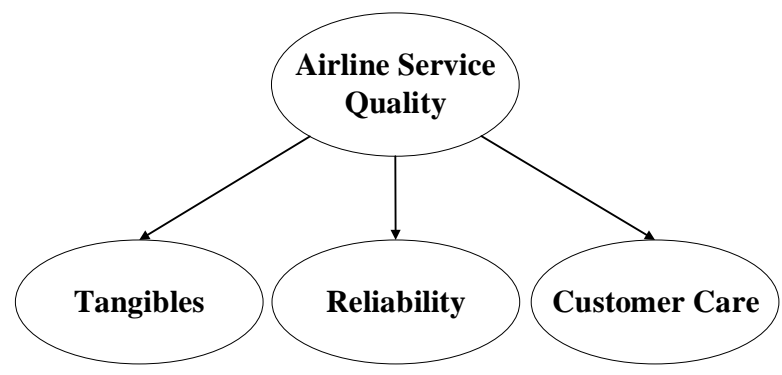

Source: Robledo, 2001

SERVPEX measures the disconfirmation concept proposed in SERVQUAL with one questionnaire. SERVPEX questionnaire items are scored on a singles scale from 'Much worse than expected' to 'Much better than expected' which includes expectations and perceptions and gets customers perceived quality. Robledo (2001) states that although Parasuraman et al. (1988) declare that SERVQUAL measurement of expectations can serve a diagnostic function for managers and offers more information to managers, but in airline industry, it is observed that passengers have uniformly high expectations across all dimensions which brings into question the diagnostic utility of the expectation measurement.

\subsection{Criticisms of SERVPEX Model}

Dabholkar, Shepherd, and Thorpe (2000) indicated that although SERVPEX is superior to SERVQUAL, it is inferior to SERVPERF in measuring service quality according to their data analysis. Criticisms of using expectation in SERVQUAL still remain with SERPPEX since researchers believe that people psychologically evaluate perceptions less than expectations (Wall \& Payne, 1973; McDougall \& Levesque, 1994; Babakus \& Boller, 1992). So the scale from less than expected to more than expected is inefficient.

Several studies such as Cunningham et al. (2004); Dabholkar et al. (2000); Park et al. (2006) have identified that SERVQUAL, SERVPERF, and SERVPEX scales are not insufficiently comprehensive to capture the service quality construct in the air transport sector with the existing measurement dimensions and suggest that it is important to reexamine the dimensions of airline service quality. 


\subsection{SSQAI Model}

SSQAI model proposed by $\mathrm{Wu}$ and Cheng (2013) is a multidimensional and hierarchical model that measures the passengers' perceptions of service quality in the airline industry. SSQAI is a performance-based measurement developed based on Dabholkar et al.'s (1996) and Brady and Cronin's (2001) and Caro and Garcia's (2007) Hierarchical Models. Wu and Cheng (2013) remarked that SSQAI is a Reliable and valid measurement instrument for assessing service quality in the airline industry. Four primary dimensions and eleven sub-dimensions of SSQAI hierarchical model are identified in Fig. 10.

$\mathrm{Wu}$ and Cheng (2013) believe that this model can demonstrate complexity of the progress of the airline passengers' perceptions more precise than previous hierarchical models of Brady and Cronin (2001) and Caro and Garcia (2007).

\section{Figure 10: SSQAI measurement scale}

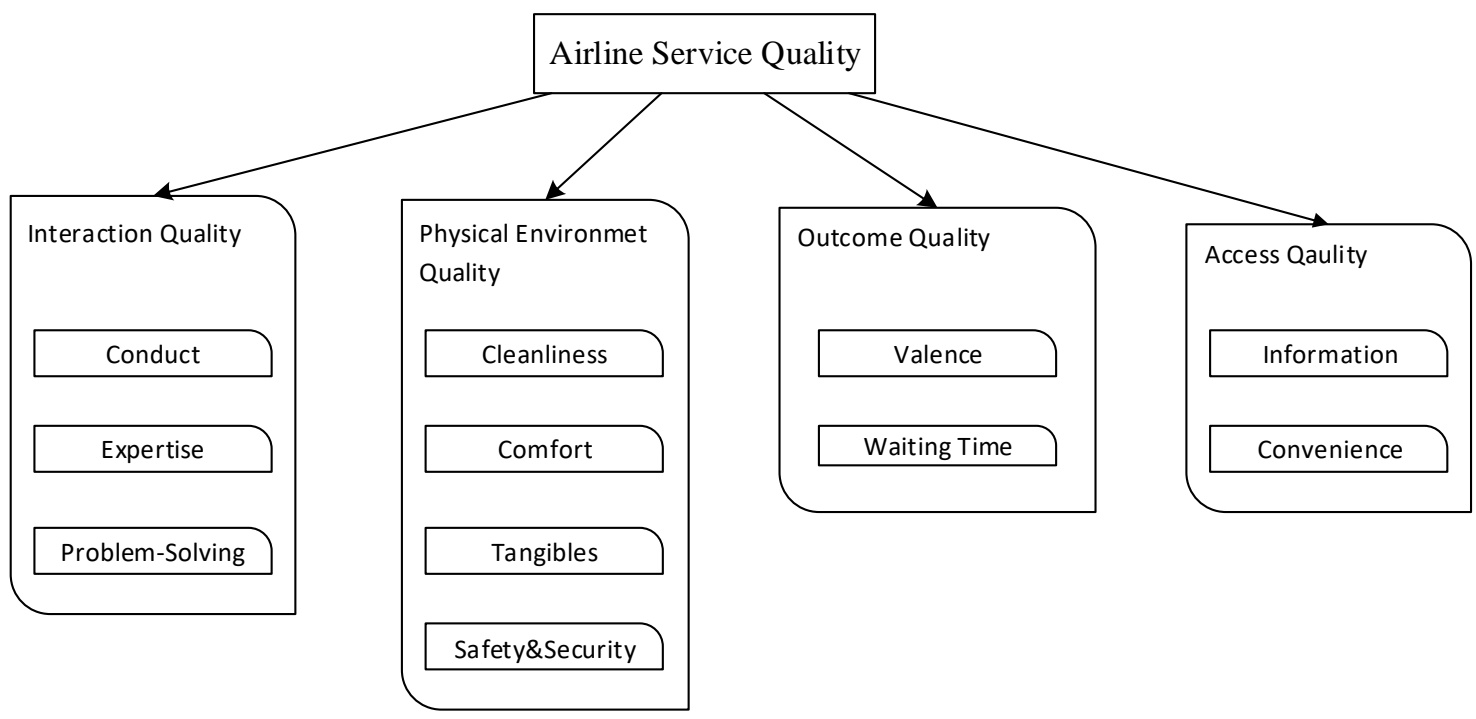

Source: Wu and Cheng, 2013

The key points of weakness and strengths of the discussed service quality models are briefly reviewed in Table 1.

\section{Table 1: Weaknesses and Strengths of Service Quality Models}

Service Quality

Model

\begin{tabular}{ll}
\hline Swan and Combs, & $\begin{array}{l}\text { Not providing measurement scale for } \\
\text { evaluating service quality }\end{array}$
\end{tabular}

Grönroos, 1984

Parasuraman et al., 1988 (SERVQUAL)

Cronin and Taylor, 1992 (SERVPERF)
Not providing criteria and measurement scale for evaluating service quality

a) Generality concept of service attributes, Overlap of dimensions

b) Ambiguity of measuring expectations

c) using two independent questionnaires, one for perception and one for expectation

Issues related to dimensions structure because of using same SERVQUAL dimensions such as generality concept and overlap of Dimensions

a) Measurement dimensions are not insufficiently comprehensive for evaluating airline service quality

\section{Developments and Strengths}

Proposed dimensions of product performance due to customer satisfaction and post-purchase

Added image dimension to swan and combs model and modified dimensions in service quality

Measures disconfirmation with $Q=\Sigma(P$ E) scale.

Introduced criteria and measurement scale for evaluating service quality

Proposed performance-based (current perception) measurement $(Q=\Sigma P)$.

Suggested importance weighted performance evaluation versus using expectations

Suggested disconfirmation measurement in a single scale from 'less than expected' to 'more than 
Dabholkar, 1994

Brady and Cronin Model, 2001

Caro and Garcia Model, 2007

SSQAI Model, 2013 b) Some issues with expectation measurement in SERVQUAL still remain with SERVPEX

a) Some of the main criteria don't contain any subcriteria inconsistent with hierarchical concept.

b) The global third-order model analysis was not test which is needed to strengthen validity of hierarchical structure

In addition of subdimension items measurements they added items directly evaluating main dimensions and overall service quality in spite of hierarchical conception that evaluation should be from low level to high level

a) Needs justifying for use in different transport systems and industries.

b) Not tested structural equation

Modeling to obtain the paths and relationship of model constructs have not been analyzed to strengthen validity

a) Needs justifying for use in different cultures and countries.

b) Needs providing measurement tool for analyzing relative importance of criteria and ranking airlines expected'

Proposed multi-level concept of evaluating service quality

applied SERVQUAL dimensions as items demonstrating different aspects of subcriteria

introduced urgent transport service quality measurement criteria in hierarchical structure

Proposed airline service quality measurement criteria in hierarchical structure

The criteria and concepts of service quality model are summarized in Table 2.

Table 2: Service quality models Criteria and concepts

Model Criteria(Subcriteria)

Concept

Swan and Combs, Instrumental performance, Expressive performance

1971

Grönroos, 1984

Image, technical quality, functional quality

Disconfirmation concept

Parasuraman

Zeithaml, and

Berry, 1985

Reliability, responsiveness, customization, credibility, competence, access, courtesy, security, communication, tangibles, and understanding

Parasuraman

Tangibles; Reliability; Responsiveness; Assurance; Empathy

Disconfirmation concept

Zeithaml, and

Berry, 1988

(SERVQUAL)

Cronin and Taylor, Same as SERVQUAL: Tangibles; Reliability;

1992 (SERVPERF) Responsiveness; Assurance; Empathy

Robledo, 2001

(SERVPEX)

Tangibles; Reliability; Customer care

Dabholkar

Thorpe and Rentz, 1996 (RSQS)

Physical aspect (Appearance, Convenience); Reliability

Disconfirmation concept

5Gap Model of Service Quality

Disconfirmation measurement with $\left(\mathrm{Q}=\sum \mathrm{P}\right.$ $\Sigma \mathrm{E})$

Brady and Cronin, 2001 confidence, Courteous /Helpful); Problem Solving; Policy;

interaction quality (attitude, behavior, and experience);

Performance-based (perception) measurement $\left(\mathrm{Q}=\sum \mathrm{P}\right)$

Disconfirmation in a single scale from 'less than expected' to 'more than expected'

Performance-based Hierarchical structure

Performance-based physical environment quality (ambient conditions, design, Hierarchical structure and social factors); outcome quality (waiting time, tangibles and valence)

Caro and Garcia 2007

Personal interaction(conduct, Expertise, Problem Solving); Design (Range of service, Operating time);

Performance-based

Hierarchical structure 
Physical Environment(Tangibles, Information); Outcome

(Punctuality, Valence)

Wu and Cheng, Interaction Quality (Conduct, Expertise, Problem solving); 2013 (SSQAI)

\section{Physical Environment Quality (Cleanliness, comfort,}

Performance-based

Tangibles, Safety\&Security); Outcome Quality (Valence,

Waiting Time); Access Quality (Information, convenience)

\subsection{Diversity of Evaluation Criteria in Airline Service Quality}

In the literature, not every two researchers have exactly applied the same criteria in evaluating airline service quality. Park et al. (2006) indicate that many airlines have difficulty in using a proper scale to evaluate service quality in order to appropriately assess and improve their service. Because of difference in cultural environment and Conditions prevailing in each society and the specific requirements of the airline industry in every country, researchers have applied various kinds of criteria and different measurement techniques in accordance of the native airline industry circumstances and nature of the environment that the research was conducted in. For example; Gilbert and Wong (2003) modified SERVQUAL and developed a 26-item questionnaire for measuring dimensions of reliability, assurance, facilities, employees, flight patterns, customization and responsiveness to compare differences between passengers' expectations with their actual airline perceived service quality.

Truitt and Haynes (1994) mentioned check-in process, convenience of transit, process of luggage, timeliness, clearness of seat, Food and beverage quality and customer complaints handling as airline service quality factors. Elliott and Roach (1993) used timelines, comfort of the seat, luggage transportation, quality of Food and beverage, check-in process and inboard service for evaluating airline service quality. Ostrowski and O'Brien (1993) defined timeliness, Food and beverage quality, comfort of the seat as the important factors of service quality and customer loyalty. Chang and Yeh (2002) found service quality criteria of On-board comfort, Airline employees, Reliability of service, Convenience of service, Handling of abnormal conditions for ranking airlines. Kuo and Liang (2011) used Costs of processing time, Convenience, Comfort, Information visibility, Courtesy of staff, Security, Reaction capacity in airline service quality measurement.

Laming and Mason (2014) mentioned on-time performance, denied boarding, mishandled baggage and customer complaints as rating factors of airlines' quality by US department of transportation. In the literature, it is stated that price is a component of sacrifice and when combined with service quality, defines a customer's value assessment. Researchers believe that price is a determinant of service value and is not part of the generally accepted understanding of service quality (Dabholkar et al., 1996; Brady \& Cronin, 2001; Caro \& Garcia, 2007; Wu \& Cheng, 2013). Pakdil and Aydin (2007) found eight elements of employees, tangibles, responsiveness, reliability and assurance, flight patterns, availability, image and empathy for evaluating airline service quality.

\subsection{Different measurement techniques in Airline Service Quality}

Pakdil and Aydin (2007) proposed a questionnaire of 34 items to measure service quality in the airline industry with modifying SERVQUAL. Instead of using standard SERVQUAL criteria and items, they applied factor analysis and extracted eight criteria. For measuring these criteria they used weighted gap using expectations minus perception scores conducted in SERVQUAL. Laming and Mason (2014) applied Spearman statistical analysis to rank 10 dimensions of airline service quality. Kuo and Jou (2014) used structural equation modeling to find the path between Service quality gain, service quality loss, satisfaction, behavioral intention, and perceived value.

While many studies have used traditional statistical techniques to introducing different criteria and test some hypotheses in airline service quality e.g.; Pakdil and Aydin (2007); Kuo and Jou (2014), others have applied Multi-Attribute Decision Making (MADM) methods to investigate airlines integrated service quality performance and to make suggestions for improvement. e.g.; Tsaur et al. (2002) used SERVQUAL dimensions to derivate attributes and performed AHP and TOPSIS in ranking airlines. They stated that courtesy, safety, and comfort are the most important attributes in airline service quality. However, in recent years, many studies have performed Fuzzy MADM techniques to achieve more precise results in evaluating airline service quality (Tsaur, Chang, \& Yen, 2002; Chang \& Yeh, 2002; Liou \& Tzeng, 2007; Liou et al., 2011). 
In the literature Fuzzy MADM analysis has been widely utilized to tackle problems involving more than one attribute or alternative in ambiguous conditions (Chang \& Wang, 2009). Moreover, some researchers have combined different measurement techniques for getting better results in the evaluation process of airline service quality. Chang and Yeh (2002) performed FMADM technique for ranking four airlines with fifteen service attributes. They found flight safety as the most important attribute in measuring airline service quality. Kuo (2011) and Kuo and Liang (2011) used Fuzzy sets, Vikor and Grey relation analysis for measuring airline service quality performance. Liou and Tzeng (2007) proposed a non-additive fuzzy integral model by applying AHP, Factor analysis (Varimax rotation with Kaiser Normalization), Fuzzy integral and Grey relation analysis to investigate the service quality of six international airlines serving Taiwan. They found that Safety and reliability emerge as the critical factors of service quality. Some of major airline service quality evaluation researches, applying different criteria and measurement techniques are reviewed in Table 3.

Table 3. Review of some of major airline service quality evaluation criteria and techniques

\begin{tabular}{|c|c|c|}
\hline Source & Measurement Technique & Criteria \\
\hline Kuo and Jou (2014) & $\begin{array}{l}\text { Structural Equation } \\
\text { Modeling (SEM) }\end{array}$ & $\begin{array}{l}\text { 5criteria, Service quality gain, service quality loss, } \\
\text { satisfaction, behavioral intention, perceived value }\end{array}$ \\
\hline $\begin{array}{l}\text { Laming and Mason } \\
(2014)\end{array}$ & $\begin{array}{l}\text { Statistical Analysis } \\
\text { (Spearman's rank) }\end{array}$ & $\begin{array}{l}\text { 10criteria, Cabin features, inflight food and drink, } \\
\text { crew and pilots, seat features, IFE, Arrival, Boarding } \\
\text { and departure, Website services, Check-in, flight } \\
\text { delays }\end{array}$ \\
\hline Chow (2014) & $\begin{array}{l}\text { Tobit Analysis, } \\
\text { ANOVA }\end{array}$ & $\begin{array}{l}15 \text { criteria, Flight delays, baggage problems, ticketing } \\
\text { problems, in-flight services, flight information, check- } \\
\text { in service, cargo problems, passenger service } \\
\text { ticketing, booking \& check-in, over sold tickets, } \\
\text { refunding animal death, services for disabled, ticket } \\
\text { price, flight cancelation, Weather conditions }\end{array}$ \\
\hline Suki (2014) & $\begin{array}{l}\text { Structural equation } \\
\text { modeling (SEM) }\end{array}$ & $\begin{array}{l}\text { 4criteria, Airline tangibles, terminal tangibles, } \\
\text { customer satisfaction, word of mouth }\end{array}$ \\
\hline $\begin{array}{l}\text { Liou, Hsu, Yeh } \\
\text { and Lin (2011) }\end{array}$ & $\begin{array}{l}\text { Grey Relation Analysis } \\
\text { (GRA), } \\
\text { Weighted Grey Gap }\end{array}$ & $\begin{array}{l}\text { 28criteria, Booking service(3), Ticketing service(3), } \\
\text { Check-in(4), Baggage handling(2), Boarding } \\
\text { process(3), Cabin service(7), Baggage claim(2), } \\
\text { Responsiveness(4) }\end{array}$ \\
\hline Kuo (2011) & $\begin{array}{l}\text { Vikor, GRA, } \\
\text { interval-valued fuzzy sets }\end{array}$ & $\begin{array}{l}\text { 14criteria-Tangibility(3)-Safety and Reliability(3), } \\
\text { Responsiveness(3), Assurance(2), Empathy(3) }\end{array}$ \\
\hline Kuo and Liang (2011) & Fuzzy sets, Vikor, GRA & $\begin{array}{l}\text { 7criteria, Costs of processing time-Convenience- } \\
\text { Comfort-Information visibility-Courtesy of staff- } \\
\text { Security-Reaction capacity }\end{array}$ \\
\hline $\begin{array}{l}\text { Liou, Tang, Yeh } \\
\text { and Tsai (2011) }\end{array}$ & $\begin{array}{l}\text { Factor analysis, Data Mining } \\
\text { (DRSA) }\end{array}$ & $\begin{array}{l}24 \text { criteria-Convenience(7), Comfort(4), ICQ(3), } \\
\text { Transportation(3), Courtesy of staff(2), Information } \\
\text { visibility(2), Security(2), Price of shop(1) }\end{array}$ \\
\hline $\begin{array}{l}\text { Tiernan, Rhoades and } \\
\text { Waguespack (2008) }\end{array}$ & $\begin{array}{l}\text { Statistical analysis } \\
\text { (F-test) }\end{array}$ & $\begin{array}{l}\text { 3criteria-On-time arrivals, baggage reports, flight } \\
\text { cancellations }\end{array}$ \\
\hline Liou and Tzeng (2007) & $\begin{array}{l}\text { AHP, Factor analysis } \\
\text { (Varimax rotation with } \\
\text { Kaiser normalization), } \\
\text { Fuzzy integral, Grey relation } \\
\text { analysis }\end{array}$ & $\begin{array}{l}12 \text { criteria, employees service(4), Safety and } \\
\text { reliability(2), On-board service(3), Schedule(1), On- } \\
\text { time performance(1), Frequent Flyer Program (1) }\end{array}$ \\
\hline $\begin{array}{l}\text { Pakdil and Aydin } \\
\text { (2007) }\end{array}$ & $\begin{array}{l}\text { Factor analysis, Weighting } \\
\text { based on weighted } \\
\text { SERVQUAL scores. }\end{array}$ & $\begin{array}{l}34 \text { criteria, Employees(4), Tangibles(5), } \\
\text { Responsiveness(6), Reliability and assurance(4), } \\
\text { flight patterns(3), Availability(3), Image(3), } \\
\text { Empathy(6) }\end{array}$ \\
\hline $\begin{array}{l}\text { Tsaur, Chang Yeh and } \\
\text { Yen (2002) }\end{array}$ & AHP, Fuzzy theory, TOPSIS & $\begin{array}{l}15 \text { criteria, Tangibility(4), Reliability(3), } \\
\text { Responsiveness(2), Assurance(3), Empathy(3) }\end{array}$ \\
\hline Chang and Yeh(2002) & Fuzzy TOPSIS & $\begin{array}{l}15 \text { criteria, On-board comfort( } 3 \text { ), Airline } \\
\text { employees(4), Reliability of service( } 3 \text { ), Convenience } \\
\text { of service(2), Handling of abnormal conditions(1) }\end{array}$ \\
\hline
\end{tabular}




\section{Discussions and Recommendations}

Finding right and proper service quality evaluation criteria is an important part of the researchers' work. Adopting appropriate criteria and applying proper evaluation techniques able us in doing a precise and accurate evaluation of service quality and briefly describe the amount of satisfaction and quality of service delivered to customers.

Taking advantage of focus group discussions and applying robust mathematical analysis for defining relative importance of criteria and checking reliability and validity of measurement instruments, aids in designing a useful and practical framework for measuring airline service quality which is able to accurately demonstrate qualification status of services provided to customers and suggests improvement in weak areas.

This review helps researchers avoid problems found in previous service quality models when constructing their evaluation frameworks. Empirical results of this research provide useful information in making better strategic decisions for improving airlines service quality and help airline leaders in creating an effective framework to accurately monitor and improve service quality in required areas.

\section{Appendix A. Supplementary material}

Supplementary data associated with this article can be found, in the online version, at https://dx.doi.org/10.14254/jems.2017.2-2.4

\section{Funding}

The authors received no direct funding for this research.

\section{Citation information}

Haghighat, N. (2017). Airline service quality evaluation: A review on concepts and models. Economics, Management and Sustainability, 2(1), 31-47. doi:10.14254/jems.2017.2-2.4.

\section{References}

Babakus, E., \& Boller, G.W. (1992). An empirical assessment of the Servqual scale. Journal of Business Research, 24, 253-268.

Brady, M. K., Cronin, J.J. (2001). Some New Thoughts on Conceptualizing Perceived Service Quality: A Hierarchical Approach. The Journal of Marketing, 65(7), 34-99.

Bolton, R. N., \& Drew, J. H. (1991). A multistage model of customers' assessments of service quality and value. Journal of consumer research, 17(4), 375-384.

Cardozo, R. N. (1965). An experimental study of customer effort, expectation, and satisfaction. Journal of marketing research, 244-249.

Carman, J. M. (1990). Consumer perceptions of service quality: an assessment of the SERVQUAL dimensions. Journal of Retailing, 66(1), 33-56.

Caro, L. M., \& Garcia, J. A. M. (2007). Measuring perceived service quality in urgent transport service. Journal of Retailing and Consumer Services, 14(1), 60-72.

Cronin, J. J., \& Taylor, S. A. (1992). Measuring service quality: a re-examination and extension. Journal of Marketing, 56(3), 55-68.

Chang, Y.H., \& Yeh, C.H. (2002). A survey analysis of service quality for domestic airlines. European Journal of Operational Research 139, 166-17.

Cunningham, L. F., Young, C. E., \& Lee, M. (2004). Perceptions of airline service quality pre and post 9/11. Public Works Management \& Policy, 9(1), 10-25.

Chang, T.-H., Wang, T.-C. (2009). Using the fuzzy multi-criteria decision making approach for measuring the possibility of successful knowledge management. Information Sciences, 179, 355-370.

Churchill Jr, G. A., \& Surprenant, C. (1982). An investigation into the determinants of customer satisfaction. Journal of marketing research, 491-504. 
Chow, C.K.W, (2014). Customer satisfaction and service quality in the Chinese airline industry. Journal of Air Transport Management, 35, 102-107.

Dabholkar, P. A., Thorpe, D. I., \& Rentz, J. O. (1996). A measure of service quality for retail stores: scale development and validation. Journal of the Academy of marketing Science, 24(1), 3-16.

Dabholkar, P. A., Shepherd, C. D., \& Thorpe, D. I. (2000). A comprehensive framework for service quality: an investigation of critical conceptual and measurement issues through a longitudinal study. Journal of retailing, 76(2), 139-173.

Elliott, K., \& Roach, D. W. (1993). Service quality in the airline industry: are carriers getting an unbiased evaluation from consumers?. Journal of Professional Service Marketing, 9(2), 71-82.

Fick, G. R., \& Ritchie, J. R. B. (1991). Measuring service quality in the travel and tourism industry. Journal of Travel Research, 30(2), 2-9.

Finn, A., \& Kayandé, U. (1997). Consistency of the relationship between retailer product and service quality. In 4th Recent Advances in Retailing and Services Science Conference, Scottsdale, Arizona.

Ghobadian, A. Speller, \& S. Jones, M. (1994). Service quality concepts and models, International Journal of Quality \& Reliability management, 11(9), 43-66.

Gilbert, D., \& Wong, R. K. C. (2003). Passenger expectations and airline service: a Hong Kong based study. Tourism Management, 24(5), 519-532.

Grönroos, C. (1982). An applied service marketing theory. European journal of marketing, 16(7), 3041.

Grönroos, C. (1984). A service quality model and its marketing implications. European Journal of Marketing, 18(4), 36-44.

Howard, J. A., \& Sheth, J. N. (1969). The theory of buyer behavior (Vol. 14). New York: Wiley.

Kuo, M.-S., \& Liang, G.-S. (2011). Combining VIKOR with GRA techniques to evaluate service quality of airports under fuzzy environment. Expert Systems with Applications, 38(3), 1304-1312.

Kuo, M. S. (2011). A novel interval-valued fuzzy MCDM method for improving airlines' service quality in Chinese cross-strait airlines. Transportation Research Part E: Logistics and Transportation Review, 47(6), 1177-1193.

Kuo, C. W., \& Jou, R. C. (2014). Asymmetric response model for evaluating airline service quality: An empirical study in cross-strait direct flights. Transportation Research Part A: Policy and Practice, 62, 63-70.

Laming, C., \& Mason, K. (2014). Customer experience-An analysis of the concept and its performance in airline brands. Research in Transportation Business \& Management, 10, 15-25.

Liou J. J.H., Hsu C.-C., Yeh W.-C., \& Lin R.-H. (2011). Using a modified grey relation method for improving airline service quality. Tourism Management, 32(6), 1381-1388.

Liou, J. J.H., \& Tzeng, G.-H., (2007). A non-additive model for evaluating airline service quality. Journal of Air Transport Management, 13, (3), 131-138.

Liou, J.J.H, Tang, C.-H., Yeh, W.-C, \& Tsai, C.-Y. (2011). A decision rules approach for improvement of airport service quality. Expert Systems with Applications, 38(11), 13723-13730.

Liou J. J.H., Hsu C.-C., Yeh W.-C., \& Lin R.-H. (2011). Using a modified grey relation method for improving airline service quality. Tourism Management, 32(6), 1381-1388.

Marsh, H. W., \& Hocevar, D. (1985). Application of confirmatory factor analysis to the study of selfconcept: First-and higher order factor models and their invariance across groups. Psychological bulletin, 97(3), 562.

Mazis, M. B., Ahtola, O. T., \& Klippel, R. E. (1975). A comparison of four multi-attribute models in the prediction of consumer attitudes. Journal of Consumer Research, 2(1), 38-52.

McDougall, G.H., \& Levesque, T.J. (1994). A revised view of service quality dimensions: an empirical investigation. Journal of Professional Service Marketing, 11(1), 189-209.

Nadiri, H., \& Hussain, K. (2005). Perceptions of service quality in North Cyprus hotels. International Journal of Contemporary Hospitality Management, 17(6), 469-480. 
Oliver, R. L. (1980). A cognitive model of the antecedents and consequences of satisfaction decisions. Journal of marketing research, 460-469.

Ostrowski, P. L., O'Brien, T. V., \& Gordon, G. L. (1993). Service quality and customer loyalty in the commercial airline industry. Journal of travel research, 32(2), 16-24.

Pakdil, F., \& Aydin, O. (2007). Expectations and perceptions in airline service: an analysis using weighted SERVQUAL scores. Journal of Air Transport Management, 13(4), 229-237.

Park, J. W., Robertson, R., \& Wu, C. L. (2006). The effects of individual dimensions of airline service quality: Findings from Australian domestic air passengers. Journal of Hospitality and Tourism Management, 13(2), 161-176.

Parasuraman, A., Zeithaml, V. A., \& Berry, L. L. (1985). A conceptual model of service quality and its implications for future research. Journal of Marketing, 41-50.

Parasuraman, A., Zeithaml, V. A., \& Berry, L. L. (1988). SERVQUAL: a multiple-item scale for measuring consumer perception. Journal of Retailing, 64(1), 12-40.

Rao, C. P., \& Kelkar, M. M. (1997). Relative impact of performance and importance ratings on measurement of service quality. Journal of Professional Services Marketing, 15(2), 69-86.

Robledo, M. A. (2001). Measuring and managing service quality: integrating customer expectations. Managing Service Quality: An International Journal, 11(1), 22-31.

Siu, N. Y., \& Tak-Hing Cheung, J. (2001). A measure of retail service quality. Marketing Intelligence \& Planning, 19(2), 88-96.

Spreng, R., \& Singh, A. (1993). Analyzing service quality in the hospitality industry using the SERVQUAL model. Service Industries Journal, 1, 324-43.

Suki N. M. (2014). Passenger satisfaction with airline service quality in Malaysia: A structural equation modeling approach. Research in Transportation Business \& Management, 10(4), 2632.

Swan, J. E., \& Combs, L. J. (1976). Product performance and consumer satisfaction: A new concept. Journal of marketing, 40(2), 25-33.

Truitt, L. J., \& Haynes, R. (1994). Evaluating service quality and productivity in the regional airline industry. Transportation Journal, 33(2), 21-32.

Tsaur S.-H., Chang T.-Y., \& Yen C.-H. (2002). The evaluation of airline service quality by fuzzy MCDM. Tourism Management, 23, 107-115.

Tiernan S., Rhoades, D., \& Blaise Waguespack. (2008). Airline alliance service quality performance: An analysis of US and EU member airlines. Journal of Air Transport Management, 14, 99-102.

Wall, T. D., \& Payne, R. (1973). Are deficiency scores deficient?. Journal of Applied Psychology, 58(3), 322.

Wu, H. C., \& Cheng, C. C. (2013). A hierarchical model of service quality in the airline industry. Journal of Hospitality and Management, 20, 13-22.

Wu, H. C., \& Hsu, F. S. (2012). A multi-dimensional and hierarchical model of service quality in the gaming industry. International Journal of Tourism Sciences, 12(3), 90-118.
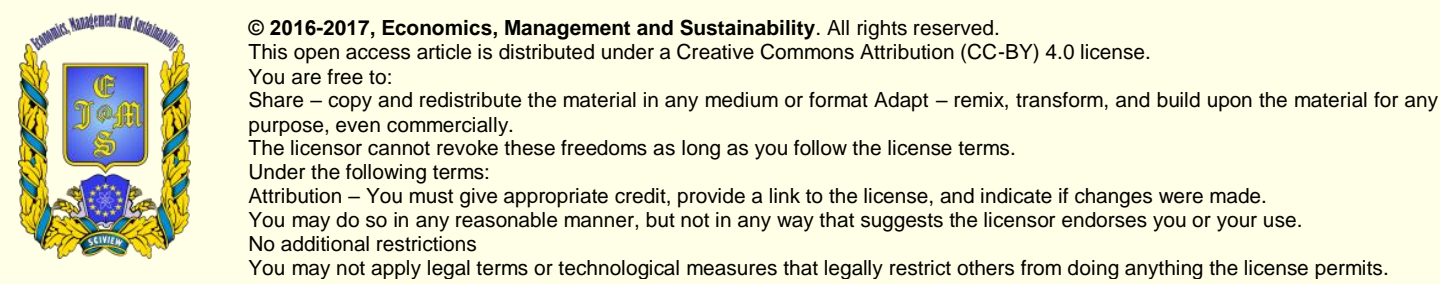

๑) 2016-2017, Economics, Management and Sustainability. All rights reserved.

This open access article is distributed under a Creative Commons Attribution (CC-BY) 4.0 license.

You are free to:

Share - copy and redistribute the material in any medium or format Adapt - remix, transform, and build upon the material for any

purpose, even commercially.

The licensor cannot revoke these freedoms as long as you follow the license terms.

Under the following terms:

Attribution - You must give appropriate credit, provide a link to the license, and indicate if changes were made.

You may do so in any reasonable manner, but not in any way that suggests the licensor endorses you or your use.

No additional restrictions

You may not apply legal terms or technological measures that legally restrict others from doing anything the license permits.

Economics, Management and Sustainability (ISSN: 2520-6303) is published by Scientific Publishing House "CSR",

Poland, EU and Scientific Publishing House "SciView", Poland

Publishing with JEMS ensures:

- Immediate, universal access to your article on publication

- High visibility and discoverability via the JEMS website

- Rapid publication

- Guaranteed legacy preservation of your article

- Discounts and waivers for authors in developing regions

Submit your manuscript to a JEMS at http://jems.sciview.net or submit.jems@sciview.net

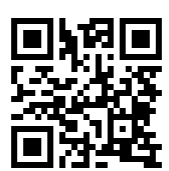

